\title{
Oxidative Stress Induced DNA Damage and Reproductive Toxicity in Male Albino Mice Orally Exposed to Sorbitol
}

\author{
Okunola A. Alabi*, Lanre R. Oladimeji , Adewale A. Sorungbe and Yetunde M. Adeoluwa
}

Department of Biology, Federal University of Technology, P.M.B. 704, Akure, Ondo State, Nigeria.

Received 27 $7^{\text {th }}$ July, 2019, Accepted $12^{\text {th }}$ October, 2019

DOI: 10.2478/ast-2019-0010

${ }^{*}$ Corresponding author

Okunola A Alabi,E-mail: oaalabi@futa.edu.ng; alabiokunola@yahoo.com

Tel: +2348034416394

\section{Abstract}

In this study, the potential DNA damage and reproductive toxicity of sorbitol was investigated using bone marrow micronucleus (MN), sperm morphology, and sperm count in mice. Five doses of 90, 45, 20,10 and $1 \mathrm{mg} / \mathrm{kg} /$ day, defined by allometry, and approximately corresponding to $1.5 \mathrm{~g}, 750 \mathrm{mg}$, $330 \mathrm{mg}, 165 \mathrm{mg}$ and $16 \mathrm{mg}$ of sorbitol daily consumption by a $70 \mathrm{~kg}$ human, respectively, were used. MN analysis showed a dose-dependent induction of micronucleated polychromatic erythrocytes and other nuclear abnormalities across the treatment groups. Assessment of sperm shape showed a significant $(\mathrm{p}<0.05)$ increase in sperm abnormalities with significant $(\mathrm{p}<0.05)$ decrease in mean sperm count in treated groups. The result of the oxidative stress biomarkers showed induction of significant $(p<0.05)$ increase in liver catalase, MDA and serum ALT and AST activities with concomitant decrease in SOD activities in exposed mice. A significant increase in weight of exposed mice were recorded when compared with the negative control. The results of this study showed the genotoxicity and reproductive effects of sorbitol.

Keywords: Sorbitol; bone-marrow micronucleus; sperm morphology; genotoxicity; oxidative stress. 


\subsection{Introduction}

Constant eating of sugar and sugar products is responsible for the emergence of some health effects. Consumption of sugar in high quantities is significantly associated with cardiovascular diseases, dental caries, obesity, high blood sugar level and can be deleterious in diabetic patients (Howard and Wylie-Rosete 2002). Therefore, there is a growing demand for sugar-free substitutes. Foods that are sugar-free are sweetened by non-nutritive sweeteners (also known as alternative or low calorie sweeteners) as sugar substitutes. Such sugar substitutes generally contain very few or no calories and therefore induce little or no glycemic response even though they taste like sugar. Sugar substitutes are now freely used in the production of processed foods like puddings, jellies, baked goods, jams, carbonated beverages, candy and powder drink mixes (Hobbs et al. 2012).

Sorbitol (also called glucitol) is a sugar alcohol which undergoes a slow metabolism in human system. Diet foods, cough syrups, toothpaste, mints, sugar-free chewing gums and mouthwash are all sweetened with sorbitol (Hobbs et al. 2012). Although, sorbitol has a minimal influence on the glycemic level and few calories when compared with sugar, yet, consumption of large quantities of sorbitol can cause diarrhea (Shafrir 1991). Sorbitol has also been found to induce DNA fragmentation in Chinese Hamster ovary cells (Johannes et al. 1992). Regular consumption of additives in food induces cytotoxic, genotoxic and carcinogenicity (Zengin et al. 2011; Hobbs et al. 2012; Saad et al. 2014). Damage to the DNA by food additives is dependent on several factors among which are their transportation across the nuclear and/or nuclear membranes, deactivation and activation of processes involving intracellular enzymes, the level of scavenging radicals and the mechanism(s) of repair possessed by the exposed cells (Howard and Wylie-Rosete 2002). Despite the regular use of sorbitol in food, there is paucity of information about its genotoxic, mutagenic and carcinogenic effects. Thus, it is of public health importance to study the potential mutagenicity and genotoxicity of this food additive so as to safe guard the health of the populace consuming it.

In most countries, genotoxicity testing has become an integral component in the evaluation of toxicity. Regulatory bodies have recommended the use of both in vitro and in vivo assays in studying genotoxic effects because no individual assay can detect all the relevant end-points in genotoxicity. Among the several standardized in vivo assays, sperm morphology and bone marrow micronucleus assays are commonly used. Sperm morphology assay is carried out to identify agents with potential to alter the process of spermatogenesis. It is highly sensitive in detecting known germ-cell mutagens and therefore, has always been carried out to identify new mutagens in germ cells (Topham 1980). Also, sperm morphology assay in mouse can be used to expose animals to a mutagen and study the relationship(s) that exists between mutagenicity and carcinogenicity (Wyrobek et al. 1983).

An alternative assay that can be used to measure a gross damage to the chromosome is micronucleus (MN) assay. In this method, cells that have completed mitosis can possess fragments of chromosome due to breakage, or as a result of rearrangement and has not been fully inserted into the daughter cell's nuclei can appear inform of small secondary nuclei (micro nuclei) in the cytoplasm. Since MN are easier to score than chromosome preparations, it is generally preferred for the evaluation of chromosome damage. Furthermore, knowing that there is no incorporation of whole chromosomes into the main nuclei, therefore, this assay can easily be used for scoring aneuploidy events, even though, an extra procedure for staining is required for the identification of MNs with whole chromosomes (Schmid 1975). In vitro and in vivo $\mathrm{MN}$ assay is recommended for the routine assessment of chemical and waste toxicity (Cimino 2006). In vitro MN assays is very important in the assessment of toxicity, however, in vivo $\mathrm{MN}$ is more relevant in the assessment of genotoxicity in humans because it considers human's pharmacokinetics, metabolism and other biological activities.

This work was designed to assess the possible cytogenotoxic and mutagenic effects of sorbitol on somatic and germ cells using mouse bone marrow MN, sperm morphology assays and sperm count. The potential mechanism of observed cytogenotoxicity via oxidative stress was also studied.

\subsection{Materials and Method}

\section{Biological materials and sorbitol purchase}

Sorbitol solution was purchased from Sigma-Aldrich, Germany (CAS No.: 50-70-4; Purity = 98\%; vapor density $<1$; vapor pressure $<0.1$ $\mathrm{mmHg}\left(25^{\circ} \mathrm{C}\right) ; \mathrm{mp} 98-100^{\circ} \mathrm{C}$ ). Male Swiss mice (albino: Mus musculus) between 6-10 weeks old and have been inbred for several generations, were purchased from Department of Physiology, University of Ibadan, Nigeria. They were kept in a well-ventilated animal house, free of pathogens at the Department of Biology, Federal University of Technology, Akure for 2 weeks acclimatization. They remained in this room till the end of the study. They were supplied with Ladokun ${ }^{\circledR}$ pelleted feed and clean water to drink. The mice were later divided into 2 categories: for MN assay, mice of 8 weeks old were used, while in sperm morphology assay, mice of 12 weeks old were used because spermatogenesis in mice is stable from 12 weeks old. All the mice were catered for in accordance with standard guidelines (National Research Council (US) Committee for the Update of the Guide for the Care and Use of Laboratory Animals 2011). The weight of the animals were recorded at the beginning and end of the experiments.

\section{Micronucleus (MN) assay}

Mice of seven groups ( 6 mice per group) were used in this assay. Each mouse/group was orally administered $0.3 \mathrm{~mL}$ sorbitol equivalent to a daily dose of 90, 45, 20, 10 and $1 \mathrm{mg} / \mathrm{kg} /$ day, defined by allometry, and approximately corresponding to $1.5 \mathrm{~g}, 750 \mathrm{mg}, 330 \mathrm{mg}, 165 \mathrm{mg}$ and $16 \mathrm{mg}$ of sorbitol daily consumption by a $70 \mathrm{~kg}$ human, respectively. The recommended daily limit of sorbitol by human is 50g (USFDA, 2018). The oral exposure was once per day for 30 consecutive days as against negative (distilled water) and positive (cyclophosphamide, 20 $\mathrm{mg} / \mathrm{kg} \mathrm{bw}$ ) controls. Bone marrow was prepared for MN assessment following the procedure of Schmid $(1975,1976)$. Briefly, mice were sacrificed through cervical dislocation, their femurs removed and the bone marrow flushed from the bones with Foetal Bovine Serum (Sigma Aldrich Cheme GmbH, Germany). At $2000 \mathrm{rpm}$, the cells were centrifuged for $5 \mathrm{~min}$ and prepared slides were stained with both MayGrunwald and Giemsa stains. Minimum of 4000 cells/mouse were scored to assess the frequency of MN in polychromatic erythrocytes 
(MNPCE). Relative size of the erythrocytes and differential staining of PCEs (bluish-purple) and normochromatic erythrocytes (NCEs, pinkish-orange) were used as indices for differentiation between the cells. Other nuclear abnormalities (NA) were also analyzed.

\section{Sperm morphology assay}

The procedure of Wyrobek et al. (1983) as modified by Bakare et al. (2005) was followed for the sperm morphology assay. Same concentrations, route of exposure and duration as in MN assay were used for this assay. Five mice were treated for each sorbitol concentration. Sperm cells were obtained from the caudal epididymes at 5 weeks from the first day of exposure, because spermatogenesis in mice completes in approximately 34.5 days according to Bartke et al. (1974). Mice were sacrificed by cervical dislocation, their epididymes were removed surgically, and two sperm suspensions were prepared from each of the testis by using physiological saline to mince the caudal. Smears were prepared on grease-free slides after staining for 45 mins with $1 \%$ Eosin $Y$. The air dried slides were coded and observed microscopically under oil immersion at $1000 x$. For each mouse, 1000 sperm cells were analyzed for possible morphological abnormalities following the criteria described by Wyrobek and Bruce (1975).

\section{Sperm counts}

Caput epididymes of the testes of each mouse used for the sperm morphology assay were removed surgically and minced with physiological saline. Numerical counting of sperms was made after preparing their suspension using Neubauers' hematocytometer at 400x (Alabi et al. 2013). Pooled sperm count from the mice in each group was expressed as mean sperm count per milliliter of suspension.

\section{Biochemical test}

Two mice per group from the MN assay were used for this test. At $24 \mathrm{~h}$ post exposure and overnight fasting, mice were lightly anesthetized and blood collected through cardiac puncture into lithium coated serum separator tubes. Liver was removed surgically, placed on ice bath to remove excess blood and weighed before it was used for biochemical analysis. This was followed by homogenization in ice cold isotonic phosphate buffer of $7.4 \mathrm{pH}$ and centrifuged $(10,000 \mathrm{~g}$ for 15 $\min , 4^{\circ} \mathrm{C}$ ). Resultant supernatant was refrigerated at $-70{ }^{\circ} \mathrm{C}$ before biochemical analysis was carried out (Agnihotri et al. 2007). Coagulated blood of the mice was centrifuged for $10 \mathrm{~min}$ at $3000 \mathrm{~g}$ to obtain serum (supernatant) which was then refrigerated at $-70{ }^{\circ} \mathrm{C}$ until analyzed. The catalase activity was measured following the method of Sinha (1972), while superoxide dismutase (SOD) was analyzed following the procedure of Misra and Fridovich (1972). Determination of protein content followed Biuret method (Gornall et al. 1949) and reduced glutathione (GSH) determination was according to the procedure described by Habig et al. (1974). Malondialdehyde (MDA), an indication of lipid peroxidation, was determined according to the report of Shokunbi and Odetola (2008). Finally, Aspartate aminotransferase (AST) and Alanine aminotransferase (ALT) activities were measured following the report of Reitman and Frankel (1957) using Randox kits (Randox Laboratories diagnostic Ltd, UK).

\section{Statistical analysis}

The SPSS ${ }^{2} 20.0$ statistical package was used in the analysis of the data. The data were reported in terms of percentage frequency and mean \pm standard error. To test the significance at the different doselevel of each assay, Dunett t- test was employed. The difference between negative control and individual dose-group was analyzed at probability level of 0.05 .

\subsection{Results}

\section{Weight}

The weight of the mice before and at the last day of exposure to different doses of sorbitol is shown in Table 1. The data showed a significant increase in weight in mice treated with $10-90 \mathrm{mg} / \mathrm{kg} /$ day of sorbitol compared to the control group in both MN and sperm morphology assays.

\section{MN assay}

Generally, the mice did not show any change in their food and water intake throughout the exposure period, however, there was weight gain across the groups at the end of the exposure period which is not statistically significant compared to the negative control (data not shown). The results of PCE, MNPCE, NCE and MNNCE observed in the bone marrow of mice exposed to different doses of sorbitol is shown in Figure 1. Compared to the negative control, the results showed a significant increase $(p<0.05)$ in MNPCE at $20 \mathrm{mg} / \mathrm{kg} /$ day and above which was dose-dependent. A dose-dependent significant rise $(\mathrm{p}<$ 0.05) in NCE (i.e. PCE:NCE) (Table 2) and MNNCE compared to the negative control was also recorded at 20,45 and $90 \mathrm{mg} / \mathrm{kg} /$ day of sorbitol (Figure 1). Different nuclear abnormalities were observed in mice exposed to different doses of sorbitol such as macrocytes, microcytes, oval, helmet, tear drop and Cabot's ring cells (Figure 2). The nuclear abnormalities had the highest occurrence in the mice exposed to $90 \mathrm{mg} / \mathrm{kg} /$ day sorbitol.

\section{Sperm morphology assay}

Different doses of sorbitol induced significant $(p<0.05)$ dosedependent abnormal sperm cells at all doses except at $1 \mathrm{mg} / \mathrm{g}$ body weight (Table 2) compared to negative control. The negative and positive controls showed $3.32 \%$ and $21.17 \%$ abnormal sperm cells, respectively. Sorbitol doses of 1,10, 20, 45 and $90 \mathrm{mg} / \mathrm{kg} /$ day induced $4.21 \%, \quad 5.91 \%, \quad 6.06 \%, \quad 12.58 \%$ and $14.37 \%$ abnormalities, respectively. Different abnormalities such as double tail, amorphous head, kidney shaped head, knoobed hook, short hoot etc were observed in exposed mice (Figure 3).

\section{Sperm count}

A decrease in a dose-dependent manner was observed in the mean sperm count across the different dose of sorbitol used (Table 3). However, a statistical significant $(\mathrm{p}<0.05)$ decrease of mean sperm count was observed at 20,45 and $90 \mathrm{mg} / \mathrm{kg} /$ day sorbitol. The mean sperm count in the negative and positive controls were $5.10 \times 10^{7} / \mathrm{mL}$ and $19.00 \times 10^{5} / \mathrm{mL}$, respectively. The decrease in mean sperm count was significant with respect to inter-dose variations but not significant with respect to inter-animal variations.

\section{Biochemical test}

The effects of sorbitol treatment on oxidative stress biomarkers in mice are shown in Table 4. The data showed a significant $(p<0.05)$ increase in the liver catalase, MDA and serum ALT and AST, with 
concomitant decrease in the liver SOD activities of the treated mice (Figures 4 and 5). A significant ( $\mathrm{p}<0.05$ ) increase in liver catalase and serum ALT and AST activities were observed at 10, 20, 45 and 90 $\mathrm{mg} / \mathrm{kg} /$ day sorbitol compared to the control group, while a significant The result of soil physicochemical parameters tabulated below: $(p<0.05)$ increase in MDA was recorded from $20 \mathrm{mg} / \mathrm{kg} /$ day dose of sorbitol upward.. However, 45 and $90 \mathrm{mg} / \mathrm{kg} /$ day dose of sorbitol induced significant $(p<0.05)$ decrease in liver SOD activities compared to the control (Figure 5).

Table 1: Summary of the average weight changes in mice exposed to different doses of sorbitol.

\begin{tabular}{ccccc}
\hline $\begin{array}{c}\text { Dose } \\
\text { (mg/kg/day) }\end{array}$ & \multicolumn{2}{c}{ Micronucleus assay } & \multicolumn{2}{c}{ Sperm morphology assay } \\
Initial weight & Final weight & Initial weight & Final weight \\
\hline Distilled water & $32.02 \pm 0.10$ & $41.06 \pm 0.04$ & $40.01 \pm 0.11$ & $49.40 \pm 0.08$ \\
1 & $32.51 \pm 0.04$ & $47.19 \pm 0.12$ & $40.51 \pm 0.06$ & $52.10 \pm 0.11$ \\
10 & $33.01 \pm 0.08$ & $57.21 \pm 0.05^{*}$ & $40.92 \pm 0.03$ & $62.00 \pm 0.03^{*}$ \\
20 & $33.28 \pm 0.10$ & $59.08 \pm 0.06^{*}$ & $41.37 \pm 0.22$ & $64.37 \pm 0.09^{*}$ \\
45 & $33.52 \pm 0.03$ & $62.17 \pm 0.01^{*}$ & $41.55 \pm 0.16$ & $64.94 \pm 0.02^{*}$ \\
90 & $33.91 \pm 0.06$ & $64.42 \pm 0.22^{*}$ & $41.92 \pm 0.02$ & $65.39 \pm 0.17^{*}$ \\
Cyclophosphamide & & & & \\
$(20 \mathrm{mg} / \mathrm{kgbw})$ & $32.04 \pm 0.11$ & $38.92 \pm 0.04$ & $40.99 \pm 0.10$ & $50.50 \pm 0.03$ \\
\hline
\end{tabular}

*significant at $\mathrm{p}<0.05$.

Table 2: Summary of morphologically abnormal sperm cells and polychromatic and normochromatic erythrocytes ratio induced in mice exposed to different doses of sorbitol.

\begin{tabular}{cccc}
\hline $\begin{array}{c}\text { Dose } \\
\text { (mg/kg/day) }\end{array}$ & $\begin{array}{c}\text { Number of Sperms } \\
\text { counted }\end{array}$ & $\begin{array}{c}\text { \% Frequency of } \\
\text { abnormality }\end{array}$ & PCE/NCE ratio \\
\hline Distilled water & 20000 & 3.32 & 4.25 \\
1 & 20000 & 4.21 & 4.18 \\
10 & 20000 & 5.91 & 3.97 \\
20 & 20000 & $6.06^{*}$ & $2.81^{*}$ \\
45 & 20000 & $12.58^{*}$ & $2.17^{*}$ \\
90 & 20000 & $14.37^{*}$ & $2.01^{*}$ \\
Cyclophosphamide & & & $1.38^{*}$ \\
\hline
\end{tabular}

*significant at $\mathrm{p}<0.05$. PCE=polychromatic erythrocytes; NCE=normochromatic erythrocytes 
Table 3: The mean (mL) sperm count of mice exposed to the different doses of sorbitol.

\begin{tabular}{cc}
\hline Dose (mg/kg/day) & Mean $(/ \mathrm{ml})$ \\
\hline 1 & $5.10 \times 10^{7}$ \\
10 & $4.86 \times 10^{7}$ \\
20 & $2.79 \times 10^{7^{*}}$ \\
45 & $1.32 \times 10^{7^{*}}$ \\
90 & $1.01 \times 10^{7^{*}}$ \\
& \\
Cyclophosphamide (20mg/kgbw) & $19.00 \times 10^{6^{*}}$
\end{tabular}

\section{*significant at $\mathbf{p}<0.05$.}

Table 4: The effects of sorbitol on the liver lipid peroxidation (MDA), catalase, superoxide dismutase (SOD), reduced glutathione (GSH), alanine aminotransferase (ALT) and aspartate aminotransferase (AST) activities.

\begin{tabular}{|l|l|l|l|l|l|l|}
\hline $\begin{array}{l}\text { Dose } \\
(\mathrm{mg} / \mathrm{kg} / \mathrm{day})\end{array}$ & $\begin{array}{l}\text { Catalase } \\
(\mu \mathrm{m} / \mathrm{mg})\end{array}$ & $\begin{array}{l}\text { MDA } \\
(\mu \mathrm{mol} / \mathrm{ml})\end{array}$ & $\begin{array}{l}\text { GSH } \\
(\mu \mathrm{m} / \mathrm{g} \text { tissue })\end{array}$ & $\begin{array}{l}\text { SOD } \\
(\mathrm{U} / \mathrm{ml} / \mathrm{Min})\end{array}$ & $\begin{array}{l}\text { ALT } \\
(\mathrm{U} / \mathrm{ml}) \\
(\mathrm{U} / \mathrm{ml})\end{array}$ \\
\hline Normal & $75.18 \pm 0.15$ & $4.98 \pm 0.04$ & $9.02 \pm 0.10$ & $5.72 \pm 0.33$ & $40.29 \pm 0.06$ & $18.47 \pm 1.00$ \\
\hline 1 & $82.37 \pm 0.32$ & $4.93 \pm 0.10$ & $9.37 \pm 0.90$ & $5.02 \pm 1.02$ & $49.30 \pm 1.00$ & $24.20 \pm 0.02$ \\
\hline 10 & $91.21 \pm 0.07^{*}$ & $7.32 \pm 0.44$ & $8.18 \pm 0.49$ & $4.24 \pm 0.67$ & $52.22 \pm 0.20^{*}$ & $31.17 \pm 0.50^{*}$ \\
\hline 20 & $96.08 \pm 0.22^{*}$ & $8.21 \pm 1.02^{*}$ & $8.00 \pm 1.00$ & $4.00 \pm 0.90$ & $56.17 \pm 0.08^{*}$ & $42.29 \pm 0.07^{*}$ \\
\hline 45 & $102.21 \pm 0.72^{*}$ & $8.38 \pm 0.58^{*}$ & $7.93 \pm 1.32$ & $3.30 \pm 0.50^{*}$ & $68.72 \pm 1.00^{*}$ & $46.04 \pm 1.02^{*}$ \\
\hline 90 & $105.03 \pm 0.18^{*}$ & $9.82 \pm 0.82^{*}$ & $7.32 \pm 0.43$ & $2.72 \pm 0.50^{*}$ & $73.72 \pm 0.04^{*}$ & $49.33 \pm 0.33^{*}$ \\
\hline
\end{tabular}

*significant at 0.05 . The data is presented as mean \pm SEM. 

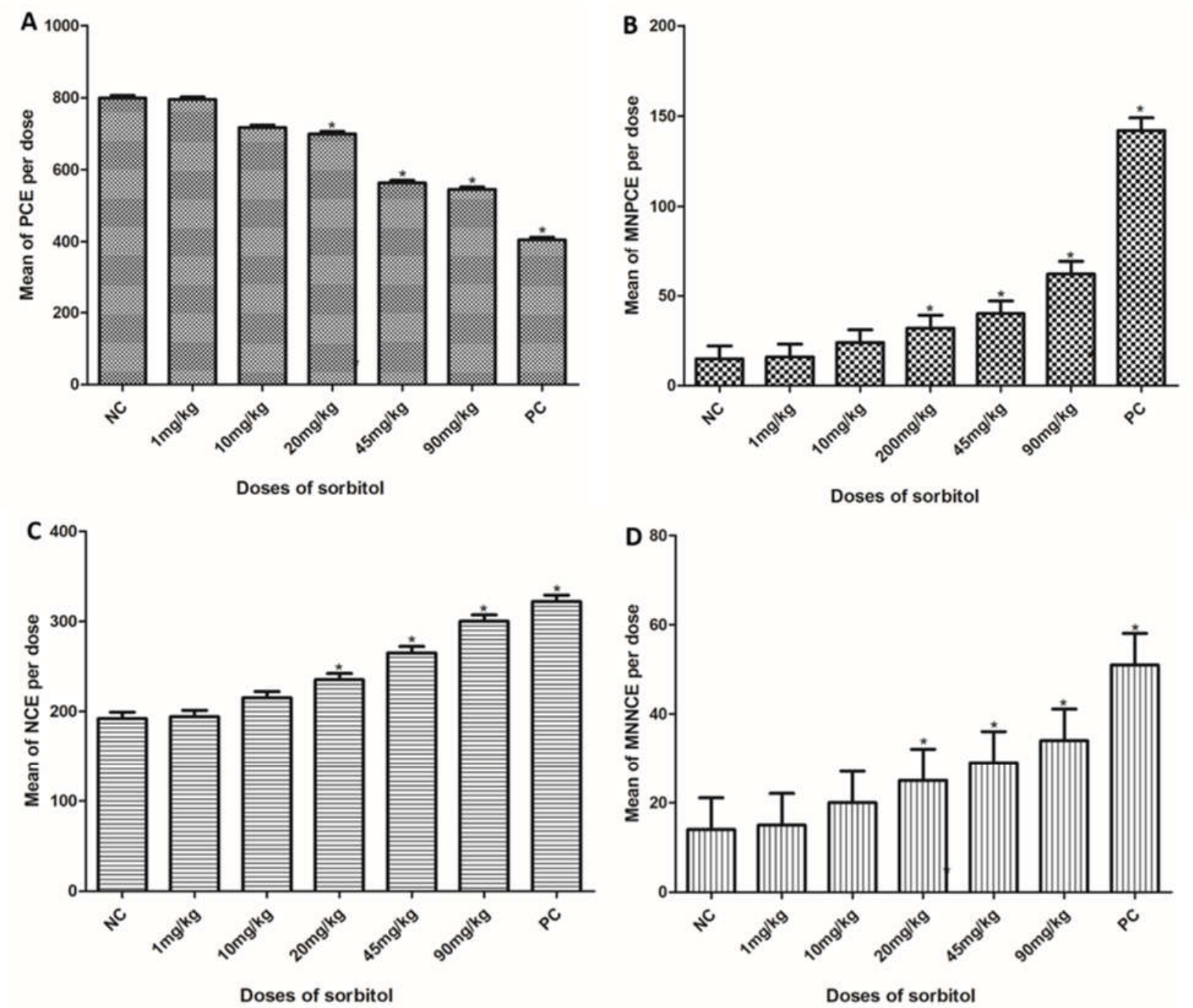

Figure 1: The mean of (A) polychromatic erythrocytes (PCE), (B) micronucleated PCE (MNPCE), (C) normochromatic erythrocytes (NCE) and (D) micronucleated NCE (MNNCE) induced in mice exposed to different concentrations of sorbitol. *significant at 0.05 compared to distilled water; NC - negative control (distilled water); PC - Positive control (cyclophosphamide). 


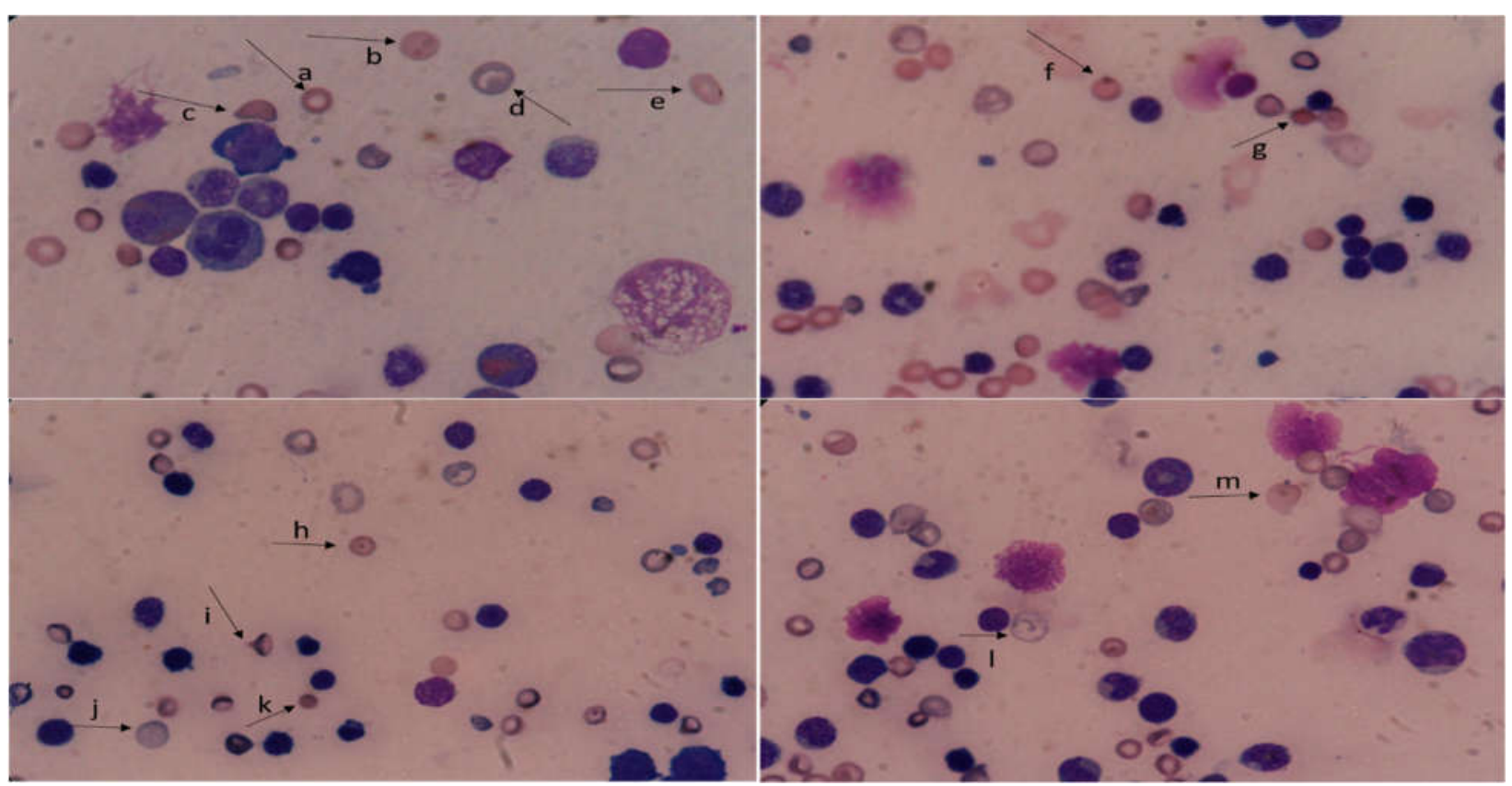

Figure 2: Micronucleus and other nuclear abnormalities induced in bone marrow of mice exposed to sorbitol. Four representative images, May-Grunwald and Giemsa stains, (magnification $\times 100$ ). a-polychromatic erythrocyte (PCE); b-macrocyte with two micronuclei; c-helmet cell; d-cabot's ring; e-oval PCE; f-micronucleated PCE; g-oval microcyte; h-micronucleated microcyte; i-cone PCE; j-normochromatic erythrocytes (NCE); k-microcyte; l-cabot's ring; m-tear drop macrocyte.

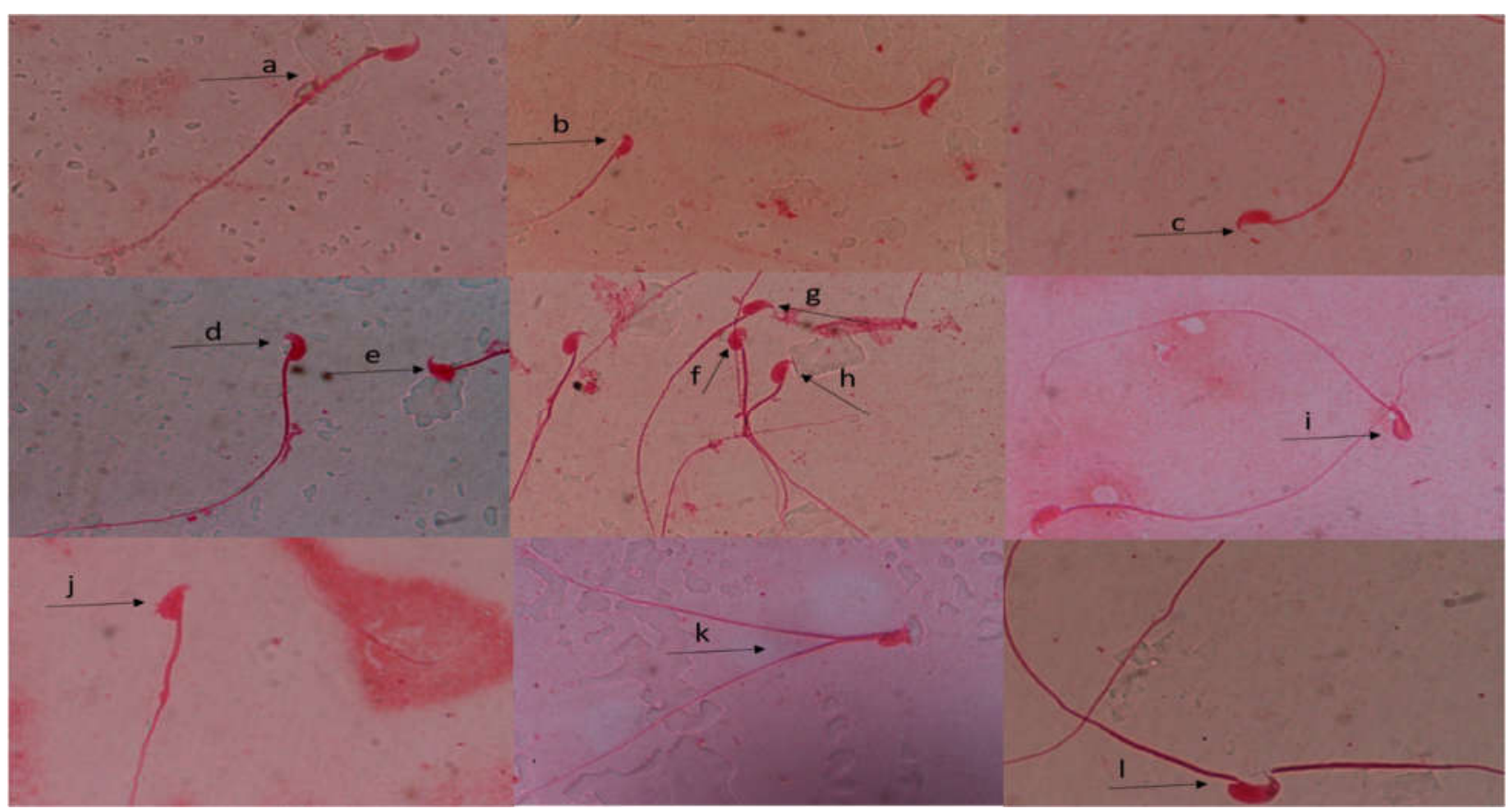

Figure 3: Abnormal sperm morphologies induced in mice exposed to different doses of sorbitol (a) normal sperm cells (b) short hook (c) knobbed hook (d) kidney head (e) misshapen head with wrong tail attachment (f) banana shaped head (g) hook at wrong angle (h) knobbed hook (i) amorphous head (j) short hook with amorphous head (k) double tail (l) wrong tail attachment. (1\% Eosin Y stain; $\times 100$ ). 


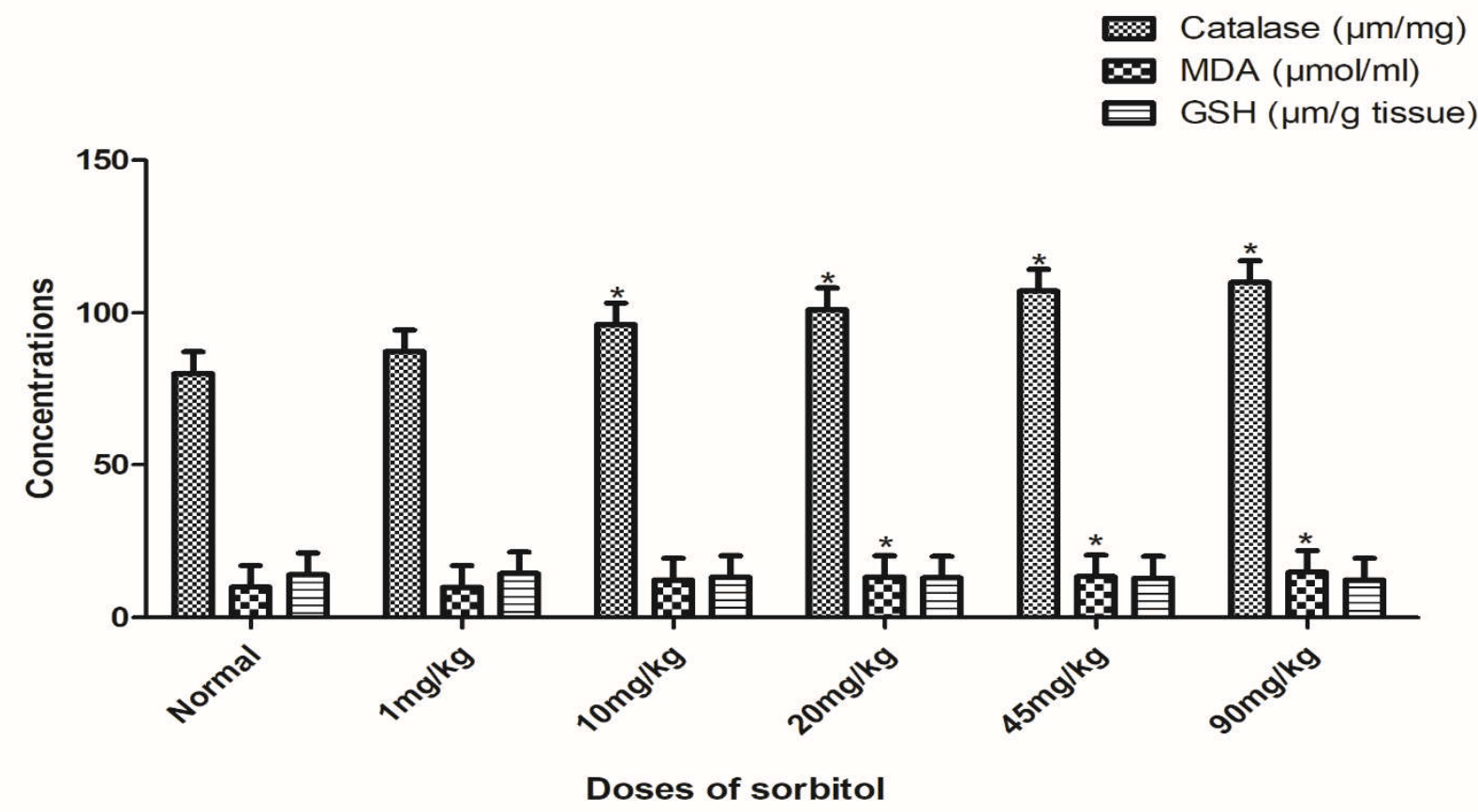

Figure 4: The effects of different concentrations of sorbitol on the liver lipid peroxidation (MDA), catalase and reduced glutathione (GSH) activities in mice. *significant at 0.05

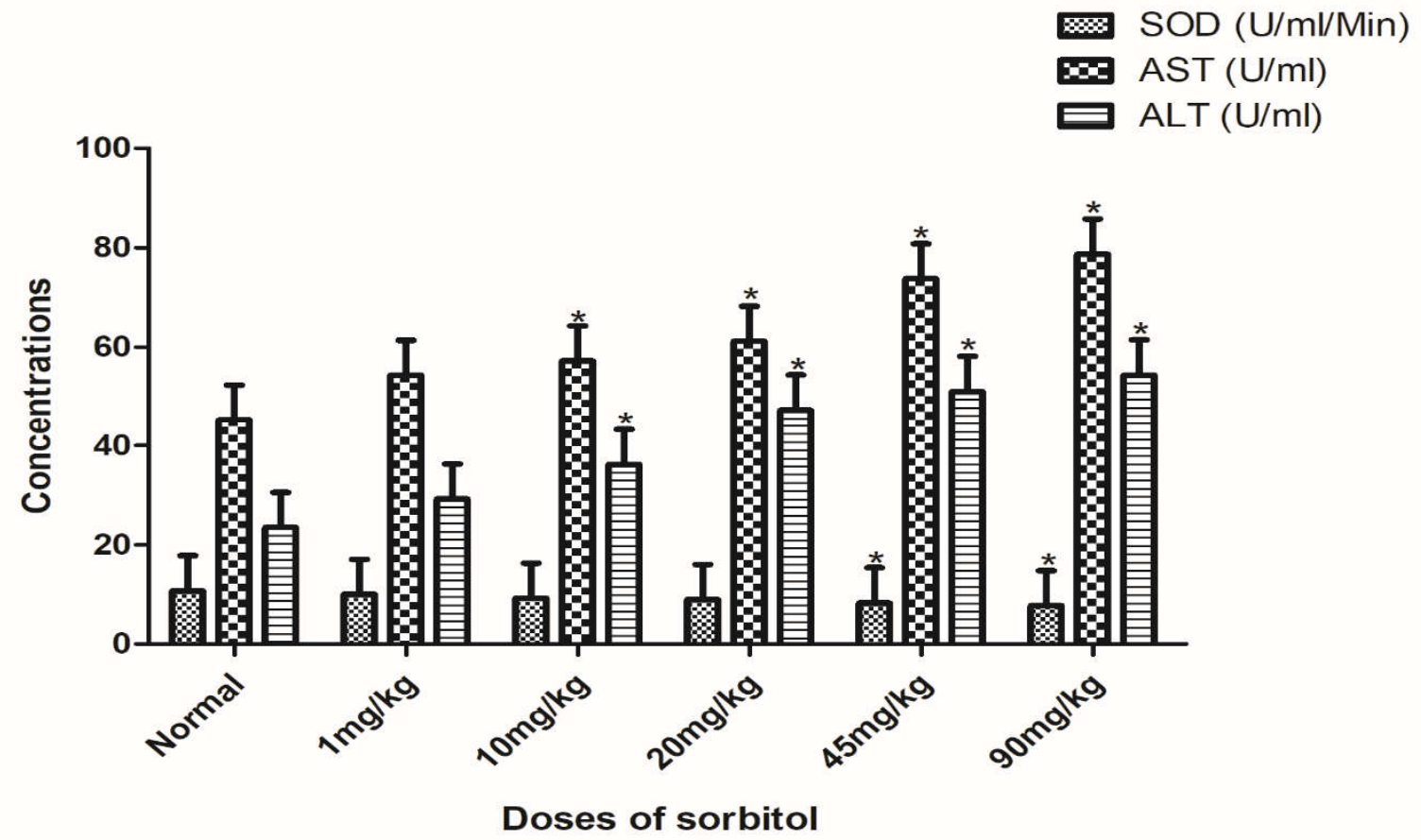

Figure 5: The effects of different concentrations of sorbitol on the superoxide dismutase (SOD), alanine aminotransferase (ALT) and aspartate aminotransferase (AST) activities in mice. *significant at 0.05 


\subsection{Discussion}

In the last decade, there was a growing public demand for sugar substitutes in food and drug industries due to the perceived health benefits of sugar-free products over sugar-containing products. This public demand has therefore made sorbitol to become an important industrial raw material which is now extensively used in industries such as chemical, pharmaceutical, food and light. Although sorbitol is used and consumed in large quantities worldwide, little but contradictory reports exist on its impact on the genetic materials and reproduction of the consumer. In the present study, we have orally exposed mice to different doses of sorbitol, doses below the daily allowed dose for human consumption. Our study has shown that sorbitol is genotoxic, thus, inducing significant amount of micronucleus and other nuclear abnormalities in somatic cells, and abnormal sperm morphology with concurrent decrease in sperm number in germ cells.

The result of our study showed a significant increase in the weight of sorbitol exposed mice compared to the control. This is could be as a result of accumulation of visceral fat as epidemiological reports have proven association between increased visceral fat and consumption of artificial sweeteners like sorbitol (Cardoso et al., 2016).

The data from the micronucleus assay showed that sorbitol is clastogenic, inducing both chromatid and chromosome breakage; and aneugenic, inducing chromosome lagging and chromosome loss, as a result of the dysfunction of the mitotic apparatus in somatic cells (Savage 1988; Alabi et al. 2019). Also, the result showed a significant difference in the PCE:NCE ratio in exposed mice and the control, which is concentration-dependent. The ratio of PCE to NCE between test agent-exposed mice and control mice indicates a cytotoxicity index of the bone marrow (Krishna and Hayashi 2000), hence, the observed results showed that sorbitol caused an increase in the rate of aging of PCE to NCE, thereby decreasing their normal life span and increasing the risk of genotoxicity. It is also an indication of a probable suppression of bone marrow proliferation resulting in bone marrow toxicity, cell depression, aging and reduction of the cell's normal life span (Singh et al. 2013; Lozovska et al. 2015).

The study further showed that sorbitol induced significant increase in nuclear abnormalities in the treated mice. The presence of microcytic hypochromic erythrocytes indicated a deficiency of haemoglobin synthesis leading to chronic anaemia. The other nuclear abnormalities observed further confirmed induction of varieties of anaemia. While the presence of oval macrocytes is an indication of megaloblastic anaemia, ${ }^{29}$ teardrop indicates myelophthisic anaemia. The presence of cabbot's ring is an indication of severe anaemia, because these are the remnants of nuclear membrane.

54|This journal is (C) The Nigerian Young Academy 2019
The data of the sperm morphology assay indicated that sorbitol is a possible germ cell mutagen especially at high dose studied, since higher doses exerted greater mutagenic effect on the mouse germ cells. The results further showed the ability of sorbitol to alter the process of spermatogenesis by the induction of several morphological abnormalities such as sperm cell with distal droplet, sperm cells with projecting filament from midpiece, banana head, double tail, kidney head, wrong tail attachment, long hook, short hook, amorphous head, hook at wrong angle, microcephaly, double head, folded sperm, swollen hook, knobbed hook, no hook, fused neck with tail and looped tail. The induced abnormalities are indication of alteration in the quality of the genetic material and can affect the overall function and motility of these sperm cells. Sperm shape abnormalities such as abnormal head defects (banana, amorphous, kidney shaped, double head) do not seem to affect the motility of spermatozoa but can significantly reduce their in vitro and the in vivo fertilizing capacity (Jeyendran et al. 1986). Also, the sperm head defects may be markers for other sperm defects that significantly impair fertility (Nikolettos et al. 1999). The induction of abnormal head may be as a result of the mutagenic effect of sorbitol on the genes for expression of acrosomes characteristics (Topham 1980). The sperm tail defects might be due to sperm aging while bended midpiece might have grown from wrong centrioles (Menkveld et al. 1990). Abnormalities with the hook are believed to be due to disorganization of the acrosomal membrane, which often leads to a change of the nuclear shape. Significant increase in the number of morphologically abnormal sperm has been associated with infertility (Wyrobek et al. 1984). Induction of abnormal sperms has been assumed to be due to an abnormal chromosome (Bruce et al. 1974), minor alteration in testicular DNA (Giri et al. 2002), point mutation (Narayana et al. 2002, Alabi and Bakare 2015) and mistakes in the spermatozoa-differentiating process during spermatogenesis (Odeigah et al. 1997, Bakare et al. 2005). The studies of Odeigah et al. (1997) and Agunbiade et al. (2012) reported that abnormalities in sperm heads might occur by physiological, cytotoxic or genetic mechanisms or alterations in testicular DNA, which in turn disrupts the process of differentiation of spermatozoa.

There was significant reduction in the mean sperm count of mice exposed to the different concentrations of sorbitol, which implies the damaging effect of sorbitol on the sperm production by altering the sperm quality during spermatogenesis and the quantity of sperm cells produced. Reduction in sperm number is also an indication of damage of the sertoli cells, since the number of sertoli cells determines the volume of sperm cells produced. Reduction in the number of viable sperm cells has been suggested to be responsible for infertility in males (Alabi et al. 2013).

Annals of Science and Technology 2019 Vol. 4 (2) 46-58 
Sorbitol cytogenotoxicity and mutagenicity in somatic and germ cells in this study is of public health concern. This is because the highest dose utilized in this study $(90 \mathrm{mg} / \mathrm{kg} /$ day) suggests that the daily allowable intake of $50 \mathrm{~g} /$ per day $/ 72 \mathrm{~kg}$ for human consumption (FDA, 2015) might be cytogenotoxic and mutagenic, especially in children. In literature, the dose of sorbitol in sweets, chewing gum, horseradish sauce and jams is as high as 350-950, 400, 110, and 80-100 mg/mL, respectively (Food Intolerance 2017). Even though the Joint FAO/WHO Expert committee on Food Additives (JECFA) and the European Union's Scientific Committee recommended that this sweetener is safe for consumption, the results of this study showed that sorbitol is cytotoxic, genotoxic and mutagenic. The genotoxicity of sorbitol reported in this study is in accordance with the report of Findikli and Turkoglu (2014), which showed that sorbitol is genotoxic. Also, Johannes et al. (1992) reported that sorbitol induced DNA damage in Chinese hamster ovary ( $\mathrm{CHO}$ ) cells, and Cardoso et al. (2016) reported that exposure to sorbitol during lactation causes metabolic alteration and genotoxic effect in rat offspring. This therefore calls for further studies, especially in humans, to ascertain the safety of sorbitol for consumption.

The possible mechanism of induced cytogenotoxicity by sorbitol was studied via oxidative stress biomarkers. The data showed that sorbitol induced a significant increase in the liver catalase and serum ALT and AST, with concomitant decrease in the liver SOD activities of the treated mice. Increased catalase activity is an indication of increased oxidative stress with potential to cause more damages to the DNA, protein and lipids (Sarkar and Sil 2014; Ferreira et al. 2015). Decrease in SOD activities, which is supposed to be the first line of enzyme defense against free radicals by catalyzing the dismutation of superoxide radical $\left(\mathrm{O}_{2}^{-}\right)$to hydrogen peroxide $\left(\mathrm{H}_{2} \mathrm{O}_{2}\right)$ and molecular oxygen $\left(\mathrm{O}_{2}\right.$ ) (Abdelhalim et al. 2015), can subsequently lead to the accumulation of these free radicals in the biological system and hence be responsible for the observed cytogenotoxicity. Indeed, the ability of sorbitol to generate reactive oxygen species have been reported by Aquilano et al. (2007). The significant increase in serum ALT and AST by sorbitol are indication of hepatocellular necrosis, which indicates the presence of hepatic injury (Friedman et al. 1996), cell membrane damage and leakage (Kaplan 1993) in exposed mice.

In conclusion, this study reports the ability of sorbitol to induced cytotoxic, genotoxic and mutagenic effects in both somatic and germ cells of mice after oral exposure for 30 days. The studies further showed that oxidative stress is a possible mechanism of action of the observed cytogenotoxicity. The report of this study calls for further study on human subjects so as to arrive at a scientific conclusion on the health effect of consumption of sorbitol by the public.

\section{Author's contribution}

Conception: AOA

Design: AOA, AAS

Execution: LRO, YMA, AAS, AOA

Interpretation: YMA, LRO, AOA

Writing the paper: LRO, YMA, AAS, AOA

\section{Funding statement}

The authors did not receive any funding from any organization or institution to carry out this study.

\section{Declaration of conflicting interest}

The authors report no conflict of interest.

\section{References}

Abdelhalim, M.A.K., Al-yed, M.S., Moussa, S.A., 2015. The effects of intraperitoneal administration of gold nanoparticles size and exposure duration on oxidative and antioxidants levels in various rat organs. Pakistan Journal of Pharmaceutical Sciences, 28:705-712.

Agnihotri, N., Kaur, H., Kaur, N., Sarotra, P., 2007. Role of oxidative stress in lansoprasole mediated gastric and hepatic protection in Wistar rats. Indian Journal of Gastroenterology, 26:118121.

Agunbiade, S.O., Okonko, I.O., Alimba, C.G., Folarin, A.C., Anugweje, K.C., 2012. Effects of a carbonaceous bottling plant effluent on albino mice sperm morphology and testes histopathology. Nature Science, 10:154-160.

Alabi, O.A., Bakare, A.A., Filippin-Monteiro, F.B., Sierra, J.A., CreczynskiPasa, T.B., 2013. Electronic waste leachate-mediated DNA fragmentation and cell death by apoptosis in mouse fibroblast (NIH/3T3) cell line. Ecotoxicology and Environmental Safety, 94:87-93

Alabi, O.A., Bakare, A.A., 2015. Cytogenotoxic Effects and Reproductive Abnormalities Induced by e-waste Contaminated Underground Water in Mice. Cytologia, 79 (3):331-340.

Alabi, O.A., Silva, A.H., Purnhagen, L.R., Souza, G.R., de Mello Júnior, L.J., Filippin-Monteiro, F.B., Dalmina, M., Pittella, F., Bakare, A.A., Creczynski-Pasa, T.B., 2019. Genetic, reproductive and oxidative damage in mice triggered by co-exposure of nanoparticles: from a hypothetical scenario to a real concern. Science of Total Environment, 660:1264-1273.

Aquilano, K., Filomeni, G., Di-Renzo, L., Di-Vito, M., Di-Stefano, C., Salimei, P.S., Ciriolo, M.R., Marfe, G., 2007. Reactive oxygen and 
nitrogen species are involved in sorbitol-induced apoptosis of human erithroleukaemia cells K562. Free Radical Research, 1-

Bakare, A.A., Mosuro, A.A., Osibanjo, O., 2005. An in vivo evaluation of induction of abnormal sperm morphology in mice by landfill leachates. Mutation Research, 582:28-34.

Bartke, A.J., Weir, A., Mathison, P., Roberson, C., Dalterio, S., 1974. Testicular function in mouse strains with different age of sexual maturation. Journal of Hereditary, 65:204-208.

Bruce, W.R., Furrer, R., Wyrobek, A.J., 1974. Abnormalities in the shape of murine sperm after acute testicular X-irradiation. Mutation Research, 23:381-386.

Cardoso, S.F., Araujo-Lima, C.F., Aiub, C.A.F., Felzenszwalb, I., 2016. Exposure to sorbitol during lactation causes metabolic alterations and genotoxic effects in rat offspring. Toxicology Letter, 260:36-45.

Cheesbrough, M., 2005. District laboratory practice in tropical countries. 2nd Edition. Cambridge university press, pp 457.

Cimino, M., 2006. Comparative overview of current international strategies and guidelines for genetic toxicology testing for regulatory purposes. Environmental Molecular Mutagen, 47:362-390.

Demir, E., Kocaoglu, S., Kaya, B., 2010. Assessment of genotoxic effects of benzyl derivatives by the comet assay. Food Chemistry and Toxicology, 48:1239-1242.

FDA. Code of federal regulations, 2015. Title 21: Foods and Drugs. Part 184: Direct food substances affirmed as generally recognized as safe (GRAS). Sec. 1835: Sorbitol. 1984, revised in 2015, Available in: http://www.accessdata.fda.gov/.

Ferreira, G.K., Cardoso, E., Vuolo, F.S., Michels, M., Zanoni, E.T., Carvalho-Silva, M., Gomes, L.M., Dal-Pizzol, F., Rezin, G.T., Streck, E.L., da Silva, M.M., 2015. Gold nanoparticles alter parameters of oxidative stress and energy metabolism in organs of adult rats. Biochemistry and Cell Biology, 93 (6):548-557.

Findikli, Z., Turkoglu, S., 2014. Determination of the effects of some artificial sweeteners on human peripheral lymphocytes using the comet assay. Journal of Toxicology and Environmental Health Science, 6:147-153.
Food Intolerance. Sorbitol content of food. 2017; Available in: http://foodintolerances.org/sorbitol-content-of-food/. Accessed on 5/9/2017.

Friedman, L.S., Martin, P., Munoz, S.J., 1996. Liver function tests and the objective evaluation of the patient with liver disease. In Hepatology: A Textbook of Liver Disease, 3rd ed.; Zakin, D., Boyer, T.D., Eds.; WB Saunders: Philadelphia, pp. 791-833.

Giri, S., Prasad, S.B., Giri, A., Sharma, G.D., 2002. Genotoxic effects of malathion: an organophosphorus insecticide, using three mammalian bioassays in vivo. Mutation Research, 514:223231.

Gornall, A.G., Barawill, J.C., David, M.M., 1949. Determination of serum protein by means of biuret reaction. Journal of Biological Chemistry, 177:751-761.

Habig, W.H., Pabst, M.J., Jakoby, W.B., 1974. Glutathione-s-transferases: The first enzymatic step in mercapturic acid formation. Journal of Biological Chemistry, 249:7130-7139.

Heddle, J.A., Hite, M., Kirkhart, B., Mavournin, K., MacGregor, J.T., Newell, G.W., Salamone, M.F., 1983. The induction of micronuclei as a measure of genotoxicity. A report of the U.S. Environmental Protection Agency Gene-Tox Program. Mutation Research, 123:61-118.

Hobbs, C.A., Swartz, C., Maronpot, R., Davis, I., Recio, L., Hayashi, S., 2012. Evaluation of the genotoxicity of the food additive, gum ghatti. Food and Chemical Toxicology, 50:854-860.

Howard, B.V., Wylie-Rosett, J., 2002. Sugar and cardiovascular disease. Circulation, 106:523-527.

ICPEMC-International Commission for Protection against Environmental Mutagens and carcinogens., 1983 Regulation approaches to the control of environmental mutagens and carcinogens, Mutation Research, 114:179-216.

Jeffery, A.M., William, G.M., 2000. Lack of DNA damaging activity of five non-nutritive sweetners in the rat hepatocyte (DNA repair assay). Food and Chemical Toxicology, 38 (4):335-338.

Jeyendran, R.S., Sehrader, S.M., van der Ven, H.H., 1986. Association of the in-vitro fertilizing capacity of human spermatozoa with sperm morphology as assessed by three classification systems. Human Reproduction, 1:305-308.

Johannes, C., Boes, R., Obe, G., 1992. Uptake of the restriction endonuclease Alul by Chinese hamster ovary cells measured by frequencies of induced chromosomal aberrations: effect of 
hypertonic concentrations of glycerol and sorbitol. Mutagenesis, 7:225-232.

Joint FAO/WHO Expert Committee on Food Additives., 1982 Toxicological evaluation of certain food additives: sorbitol. Twenty-sixth report. WHO Technical Report Series 683, Geneva. pp. 218-228.

Kaplan, M.M., 1993. Laboratory tests. In Diseases of the Liver, 7th ed.; Schiff, L., Schiff, E.R., Eds.; JB Lippinocott: Philadephia, PA, USA, pp. 108-144.

Krishna, G., Hayashi, M., 2000. In vivo rodent micronucleus assay: Protocol, conduct and data interpretation. Mutation Research, 455:155-166

Kumar, G., Srivastava, N., 2011. Genotoxic effects of too commonly used food additives of boric acid and sunset yellow in root meristems of Trigonella foenum-grucum. Iran Journal of Environmental Health Science, 8:316-361.

Lozovska, Y.V., Naleskina, L.A., Lukyanowa, N.Y., Todor, I.M., Chekhun, V.F., 2015. Assessment of the Geno- and Cytotoxic Action of Colloidal Gold Nanoparticles on the Bone Marrow Erythroid Cell Lines and Tumors in Animals with Ehrlich Ascites Carcinoma. Cytology and Genetics, 49 (1):42-48.

Menkveld, R., Stander, F.S., Kotze, T.J., Kruger, T.F., van Zyl, J.A., 1990. The evaluation of morphological characteristics of human spermatozoa according to stricter criteria. Human Reproduction, 5:586-592.

Misra, H.P., Fridovich, I., 1972. The role of superoxide anion in the autooxidation of epinephrine and a simple assay for superoxide dismutase. Journal of Biological Chemistry, 247:3170-3175.

Narayana, K., D’Souza, U.J.A., Rao, K.P.S., 2002. Ribavirin-induced sperm shape abnormalities in Wistar rat. Mutation Research, 513:193-196

National Research Council (US) Committee for the Update of the Guide for the Care and Use of Laboratory Animals. Guide for the Care and Use of Laboratory Animals, 8th ed. National Academies Press, Washington, DC. 2011.

Nikolettos, N., Kiipker, W., Demirel, C., Schopper, B., Blasig, C., Sturm, R., Felberbaum, R., Bauer, O., Diedrich, K., Al-Hasani, S., 1999. Fertilization potential of spermatozoa with abnormal morphology. Human Reproduction, 14 (1):47-70.
Odeigah, P.G.C., Nurudeen, O., Amund, O.O., 1997. Genotoxicity of oil field wastewater in Nigeria. Hereditas, 126:161-168.

OECD., 2001. OECD guideline for testing chemicals: Acute oral toxicityfixed dose procedure. OECD Publishing, Paris. 2001; Available at: https://ntp.niehs.nih.gov/iccvam/suppdocs/feddocs/oecd/o ecd_gl420.pdf.

Reitman, S., Frankel, S., 1957. A colorimetric method for determination of serum glucose oxaloacetate and glutamic pyruvate transaminases. American Journal of Clinical Pathology, 28:5356.

Saad, A., Khan, F.A., Hayee, A., Nasir, M.S., 2014. A review on potential genotoxicity of artificial sweetners vs safety of stevia. A natural bio-sweetener. Journal of Biology and Agricultural Health, 4 (15):1-12.

Sarkar, A., Sil, P., 2014. Iron oxide nanoparticles mediated cytotoxicity via PI3K/AKT pathway: Role of quercetin. Journal of Food and Chemical Toxicology, 71:106-115.

Savage, J.R., 1988. A comment on the quantitative relationship between micronuclei and chromosomal aberrations. Mutation Research, 207:33-36.

Schmid, W., 1975. The micronucleus test. Mutation Research, 31:9-15.

Schmid, W., 1976. The micronucleus test for cytogenetic analysis. In Chemical mutagens, principles and methods for their detection, Vol. 4, ed. A. Hollander, 31-53. New York: Plenum Press.

Shafrir, E., 1991. Fructose/sucrose metabolism its fisiological and pathological implications. In: Kretchmer N, Hollenbeck CB. (Ed.). Sugars and Sweeteners. BocaRaton: CRC Press. p. 63-98.

Shokunbi, O.S., Odetola, A.A., 2008. Gastroprotective and antioxidant activities of Phyllanthus amarus extracts on absolute ethanol induced ulcer in albino rats. Journal of Medicinal Plants Research, 2:261-267.

Singh, S.P., Kumari, M., Kumari, S.I., Rahman, M.F., Maboob, M., Grover, P., 2013. Toxicity assessment of manganese oxide macro and nanoparticles in wistar rats after 28 days of repeated oral exposure. Journal of Applied Toxicology, 33 (10):1165-1179.

Topham, J.C., 1980. Chemically induced transmissible abnormalities in sperm-head shape. Mutation Research, 70:109-114. 
United State Food and Drug Administration-USFDA., 2018. Food for human consumption. Code of Federal Regulations. Title 21, volume 3. Cite: 21CFR184.1835.

Wyrobek, A.J., Bruce, W.R., 1975. Chemical induction of sperm abnormalities in mice. Proceedings of the National Academy of Sciences of the United States of America 72: 4425-9. Wyrobek, A.J., L.A. Gordon, J.G. Burkhart, M.W. Francis, R.W. Kapp Jr, G. Letz, H.G. Malling, J.C. Topham, and M.D. Whorton. 1983. An evaluation of the mouse sperm morphology test and other sperm tests in non-human mammals. A report of the United
States Environmental Protection Agency Gene -Tox Programme. Mutation Research, 115:1-72.

Wyrobek, A.J., Watchmaker, G., Gordon, L., 1984. An evaluation of sperm tests as indicators of germ-cell damage in men exposed to chemical or physical agents. Teratogen Carcinogen and Mutagen. 4 (1):83-107.

Zengin, N., Yuzbasioglu, D., Unal, F., Yilmaz, J., Aksoy, H., 2011. The evaluation of the genotoxicity of two food preservatives: sodium benzoate and potassium benzoate. Food and Chemical Toxicology, 49:763-769. 